\title{
IMPLEMENTATION OF BALANCE SCORECARD AND KEY PERFORMANCE INDICATOR ON CUSTOMER SERVICE EMPLOYEE PRODUCTIVITY
}

\author{
Caecilia Ruli ${ }^{1} \bowtie$ \\ lia.larissa17@gmail.com \\ Heru Kristanto ${ }^{1}$ \\ ${ }^{1}$ Faculty of Business \\ Universitas Kristen Duta Wacana \\ Dr. Wahidin Sudirohusodo str. No.5-25, Yogyakarta, Indonesia, 55224
}

$\triangle$ Corresponding author

\begin{abstract}
This research aims to find out the implementation of balance scorecard and key performance indicator on customer service employee productivity. Participants of this study were customer service employees. This method of research is qualitative. Data collection techniques by means of observation, documentation, and interviews. Qualitative data analysis used includes the stages of data analysis is data reduction, data display, and conclusion drawing. The research concluded that the implementation of Balance Scorecard and Key performance indicator as a Productivity Meter for Customer Service Employees in Larissa Aesthetic Center has been good. This can be proven by the increase in Rupiah Revenue from MVG Customer service in 2019 amounting to Rp. 2,201,831,000. A customer perspective, calculated based on customer retention, shows that the customer retention has increased by $0.7 \%$. Thus, it can be concluded, that a customer perspective as measured by customer retention is good. This research has contributed to uncovering the influence of Balanced Scorecard on the design of performance management systems in companies and non-profit organizations that are beneficial for corporate evaluation and academic studies. For further research it is recommended, that it extends the observation period by comparison between years, using different organizations or companies, and as well as the addition of research variables.
\end{abstract}

Keywords: balance scorecard, key performance indicator, employee productivity, company

DOI: $10.21303 / 2504-5571.2021 .001988$

\section{Introduction}

Business competition is increasingly tight and fierce, making an organization encouraged to continue to survive in the face of such competition. Therefore, organizations need a more competitive advantage compared to competitors in order to win the competition in the market. Several factors can determine the success of an organization, especially in the human resources in the organization. This is because human resources in an organization are the most important assets or things and their role as the implementing subject in all operational activities of the organization is urgently needed [1].

Without human resources in an organization, the organization will not achieve success in its goals. However, the development of technology today makes problems related to human resources the main spotlight. The intended problem is that there are still many low or poor quality human resources. The quality of human resources in the organization itself is strongly supported by the adequacy of the needs, desired by employees. If an employee feels fulfilled his/her needs then the employee will give more energy to the organization to produce a high level of work productivity.

In the management concept, employees as the most important resource in the organization are expected to be better able to utilize and increase the productivity of their employees. Make full use of human resources contain the understanding of organizational structure development and workforce quality development both actual and potential. This effort demands the involvement of all employees of the organization where everyone feels the importance of increased productivity. 
Therefore, human labor needs to get special attention because the effective use of human labor is the key to increased productivity.

Improved work productivity is done by a dynamic, creative and open person, but still critical and responsive to new ideas and changes. A productive employee is a skilled employee and able to understand his/her work according to what is expected [2]. Productivity in an organization is one of the components that must be owned, this is because if the organization achieves the goals that have been set then the level of work productivity in employees must also be higher to support the achievement.

In line with this, performance measurement assessment is basically an assessment of a number of activities, conducted by individuals or groups related to the organization's operational activities in achieving the objectives [3].

A performance assessment of the organization can evaluate periodically the activities that have been carried out, so that the expected performance patterns can be achieved. A performance assessment in the current era is conducted through the Balanced Scorecard approach, which is intended to describe short-term and long-term, financial and non-financial, internal and external performance. Kaplan \& Norton developed a more comprehensive organizational success benchmark called Balanced Scorecard [4].

The definition of Balanced Scorecard is a set of measures that give the top manager a quick but comprehensive business view including a financial measure that informs the results of actions taken, complementing the size of the finances with operational measures on customer satisfaction, internal processes, and innovation activities and organizational improvement-operational measures that are the drivers of future financial performance [5].

As a performance assessment, a balanced scorecard provides a comprehensive framework to lay out the mission into strategic objectives. These goals can be formulated because Balanced Scorecard uses four perspectives: finance, customer, internal business processes, and learning and growth. The financial perspective will assess the financial objectives that the organization needs to achieve in realizing its vision. Customer perspectives provide an overview of the intended market segment as well as the demands of their needs in an effort to achieve certain financial goals. The internal business process perspective provides an overview of the processes that must be built to serve customers and to achieve specific financial goals. The perspective of learning and growth is a boost to build personnel competition, information system infrastructure and the atmosphere of the work environment, needed to realize financial goals, customers, and internal business processes [6].

Innovative companies use balanced scorecards as a revolutionary tool to mobilize employees to achieve the company's mission and is a strategic management system for setting long-term goals and strategies [7]. Indicators in performance measurement must be clear and measurable so as to produce effective performance and become an evaluation tool for the company. Therefore, it takes a clear relationship between vision, mission, and strategy with the performance to be achieved as well as the indicators, used to measure performance. Balanced Scorecard is able to create a clear causal relationship between vision, mission, and strategy with clear indicators from different perspectives. Moreover, the results of performance measurement can also be used as the basis for an incentive or reward and punishment system in a company that ultimately fosters work motivation for employees.

The use of Balanced Scorecard perspective also needs to be done at Larissa Aesthetic Center. Larissa Aesthetic Center is a skincare service that offers services in the field of health care and beauty of skin, hair, and body. Some skincare that is now found in many major cities are skincare that combines facial and body beauty services, and skin health consultations.

Indonesia is a country with a fairly large beauty products market, judging by the number of women aged $15-64$ years, which is $33.23 \%$ in 2014 . This situation becomes a great potential that is utilized by the beauty industry services in Indonesia. With so many skincare in Indonesia, Larissa Aesthetic Center is making it a continuous effort to retain customers and increase customers in their organization. Therefore, to achieve this goal, the level of work productivity at Larissa Aesthetic Center is also needed to be continuously improved. To know the level of employee productivity, 
it is necessary to look at the number of visitors Larissa Aesthetic Center for the last three years. Here are the visitor data and developments of Larissa Aesthetic Center in 2017-2019, as in Table 1 and Table 2.

Table 1

Larissa Aesthetic Center Visitor Data for 2017-2019

\begin{tabular}{cccc}
\hline Bulan & & Tahun & $\mathbf{2 0 1 9}$ \\
\cline { 2 - 4 } & $\mathbf{2 0 1 7}$ & $\mathbf{2 0 1 8}$ & 4.634 \\
January & 4.209 & 4.529 & 4.294 \\
February & 4.221 & 4.011 & 4.856 \\
March & 5.242 & 4.961 & 4.777 \\
April & 5.164 & 4.526 & 4.926 \\
May & 4.983 & 4.884 & 5.133 \\
June & 5.185 & 4.469 & 5.026 \\
July & 5.146 & 5.274 & 4.807 \\
August & 5.078 & 4.730 & 4.518 \\
September & 4.553 & 4.597 & 5.222 \\
October & 4.411 & 5.057 & 4.591 \\
November & 4.551 & 4.557 & 5.172 \\
December & 4.783 & 4.922 & 57.956
\end{tabular}

Source: Data Primer

Tabel 2

Larissa Aesthetic Center Visitor Development in 2017-2019

\begin{tabular}{ccccc}
\hline Years & Number of visitors & Change & Information & Percentage \\
\hline 2017 & 57.526 & - & - & - \\
2018 & 56.517 & 1.009 & Down & $1,75 \%$ \\
2019 & 57.956 & 1.439 & Up & $2,55 \%$
\end{tabular}

Source: Data Primer

Based on Table 1 data above, it appears that there were fluctuations in the number of visitors to Larissa Aesthetic Center during 2017 to 2019. In 2017 to 2018 there was a decrease in the number of visitors by 1,009 people or by $1.75 \%$, and in 2018 to 2019 Larissa Aesthetic Center experienced an increase in the number of visitors by 1,439 people or by $2.55 \%$. From this data can be seen the instability of the number of visitors in Larissa Aesthetic Center. Some of the factors behind this instability are services, provided not in accordance with customer expectations or due to the emergence of similar competitors who are able to provide better services, such as in terms of service of workers.

Based on the description above, the researchers are interested to conduct a study with the title "Implementation of Balance Scorecard and Key Performance Indicator as a Measure of Productivity of Customer Service Employees.

This research aims to find out the implementation of balance score card and key performance indicator on customer service employee productivity.

\section{Research method}

Participants of this study were customer service employees in skincare. This research is a qualitative descriptive one. Descriptive terms come from English to describe which means to depict or portray something [8]. Qualitative research is a particular tradition in social sciences that fundamentally depends on human observation both within its region and in its terminology [9], [10]. This study uses a case study approach. 
Researchers try to study the phenomena that occur in the organization and then explored logically according to scientific rules, so that qualitative approaches allow researchers to conduct a fairly broad and in-depth discussion of an organization. Thus, this study can describe the Implementation of Balance Scorecard and Key performance indicator as a Measure of Productivity of Customer Service Employees.

In this study, researchers used data collection techniques by means of observation, documentation, and interviews. Qualitative data analysis used includes the stages of data analysis is data reduction, data display, and conclusion withdrawal [11].

\section{Result and discussion}

The Company is an organization that has a specific purpose in conducting its business. Employee productivity in the company is an important issue, especially in the era of globalization, whose information is needed by the company's stakeholders. Improving the work productivity of company employees has always been a strategic issue for any business, operating in the market economy, therefore measuring employee work productivity is an important basis for business survival and development. To evaluate the productivity of employees in the company, it is necessary to use financial and non-financial indicators.

Work productivity itself can be interpreted as the use of human resources, skills, technology and management to improve life to make it better than the previous day. An employee can be said to be productive if he/she is able to produce more products compared to other employees at the same time [12].

Performance or productivity assessment in a company or organization is a measurement process in achieving a goal that has been set by a company. A performance assessment can detect weaknesses or deficiencies that still exist in the company, for further improvement in the future [13]. The review was conducted to determine the company's performance measurement system and as a reference for the company's own internal growth. Thus, it can be concluded, that the measurement of employee productivity is one of the very important factors for the company to assess the extent of the success of the company that has been achieved.

So far, performance measurements that are widely used by companies are traditional performance measurements, which only focus on financial measures. Financial measures alone can not provide a real picture of the state of the company because it does not pay attention to other things outside the financial side, such as the customer side, which is an important focus for the company and employees, when these two things are the driving wheels for the company's activities [14]. To overcome the limitations of traditional performance measurement, the new performance measurement system is balanced scorecard. Balanced Scorecard translates missions and strategies into a variety of objectives and sizes, organized into four perspectives: finance, customer, internal business processes, and learning and growth [14].

Balanced Scorecard is not only a gauge of the company's performance, but is a form of total strategic transformation to all levels in the organization. With comprehensive performance measurement, not only measuring financial aspects, but merging financial and non-financial measures, the company can run better. In addition, the four perspectives in the Balanced Scorecard also allow for a balance between short-term and long-term goals. In line with this, Balanced Scorecard basically provides the company's management system to invest in the long term for several things. First the customer. Second, employee learning and growth, including management. Third, internal business processes to obtain financial results that enable the development of business organizations rather than simply managing the bottom line to spur short-term income [15].

In this study, the aim was to measure the productivity of customer service work in Larissa Aesthetic Center with the Balanced Scorecard approach, reviewed from four perspectives, namely:

1. Financial Perspective

The financial aspect is the result of a process that continues due to the increase in resources, owned by a person or company [16]. With the implementation of good activities a positive response from the community will then be gotten. In this study, we tried to measure the performance of financial perspectives, calculated based on the rupiah revenue, obtained from MVG Customer 
service. The results of the research that has been done show that the performance of financial perspectives, calculated based on the rupiah revenue, obtained from MVG Customer service, has been good, this is due to the increase in Rupiah Revenue from MVG Customer service in July to December 2019 amounting to Rp. 2,201,831,000 from the acquisition of MVG Customer service in January to June 2019 with a total of Rp. 1,922,317,500.

\section{Customer Perspective}

The customer perspective in Balanced Scorecard aims to increase value for customers [15]. The customer perspective can be measured by looking at customer satisfaction with the service they receive [17]. In this study, we tried to measure the customer perspective based on customer retention. Based on the calculation of customer retention data it can be known, that in the period January to June 2019, the customer retention decreased. This can be seen in the national average in June 2019, decreased from May 2019 with a difference of $0.3 \%$. Meanwhile, in the period July 2019 to December 2019 it continues to increase. This can be seen in the national average customer retention of $38 \%$, obtained in December 2019, the value is higher than the november 2019 of $37.3 \%$. This indicates that the customer retention has increased by $0.7 \%$. Thus, it can be concluded, that the customer perspective as measured by customer retention is good.

3. Internal Business Perspective

In the internal business perspective of the Balanced Scorecard, managers must identify the most critical processes to achieve the goal of improvement for customers and the goal of increasing value for shareholders [15]. This study was conducted to measure the internal perspective of business processes based on the data of satisfied customer surveys. Based on the calculation of survey data of satisfied customers, it can be known, that the aspect of Hospitality and courtesy of doctors in serving customers get a score of 3.73, aspects of Hospitality and courtesy CS in serving customers get a score of 3.67, and the aspect of Honesty and patience of doctors in providing service obtained a score of 3.67. Terms of product price and maintenance get a score of 3.67 and the aspect of cleanliness and neatness of the treatment room gets a score of 3.67. In accordance with the score, obtained from each customer, then all aspects obtained an average score of 3.68. Thus, it can be concluded, that customers are satisfied with the service, provided by Larissa Aesthetic Center.

4. Learning and Growth Perspectives

The fourth perspective in the Balanced Scorecard is to develop goals and measures that control the learning and growth of the organization. If the goals, set in the perspective of finance, customer, and internal business processes, identify where organizations must excel to achieve breakthrough performance, then the goals in the learning and growth perspective provide an infrastructure that enables goals from all three previous perspectives to be achieved. The goal in this perspective is the controller to achieve output excellence from the three previous perspectives [15]. In this study the perspective of growth and learning was determined by measuring based on the number of retention packages sold. The results from the data showed that in January to June 2019 the productivity on the number of retention packages sold was 51,107. Meanwhile, in July to December 2019 the productivity on the number of retention packages sold was 110,440. The total shows that the productivity on the number of retention packages sold increased by 59,333 , so it can be concluded, that the perspective of growth and learning at Larissa Aesthetic Center has been good.

In accordance with the description above, it can be concluded, that the implementation of Balance Scorecard and Key performance indicator as a measure of productivity of customer service employees in Larissa Aesthetic Center has been good. In line with this, the research, conducted by Tahaka (2013), shows that the results of performance measurement from four perspectives Balanced Scorecard testify that the company's performance is considered quite good [18]. The financial perspective is quite good because it has improved from month to month, and in the customer perspective, customer acquisition is not yet maximized, while in the aspect of customer retention, it is considered good to maintain the number and customer satisfaction; Larissa Aesthetic Center has been quite good at handling customer complaints. In the perspective of internal business processes, there is an increase in customer service productivity. In the growth and learning perspective, judging by employee productivity, Larissa Aesthetic Center is able to improve employee 
competence through training selling skills well so that key performance indicators of customer service productivity increase.

The limitations in conducting this research are as follows:

1) Performance measurement in this study is based only on indicators that are limited to the general overview of the company, namely on the availability of data, as well as surveys and interviews conducted;

2) The limitation of the author's knowledge influenced her in the preparation of this thesis, so that the author has not been able to process the existing data and information in more detail and accurately, as well as develop more creative ideas.

The prospects for further research are:

1) It is expected, that further research can extend the observation period by comparison between years;

2) It is expected, that further research uses different organizations or companies as well as the addition of research variables.

\section{Conclusion}

The research concluded that the implementation of Balance Scorecard and Key performance indicator as a Productivity Meter for Customer Service Employees in Larissa Aesthetic Center has been good. This can be proven by the increase in Rupiah Revenue from MVG Customer service in 2019 amounting to Rp. 2,201,831,000. The customer perspective, calculated based on customer retention shows that customer retention has increased by $0.7 \%$. Thus it can be concluded, that the customer perspective as measured by customer retention is good. Furthermore, in the internal business perspective, measured based on the survey of satisfied customers, an average score of 3.68 is known, the score shows that customers are satisfied with the service, provided by Larissa Aesthetic Center. The learning perspective and the growth, measured by the number of retention packages sold, shows that the productivity on the number of retention packages sold increased by 59,333, so it can be concluded, that the perspective of growth and learning at Larissa Aesthetic Center has been good.

Based on the research results, it can be suggested for the Head of the Larissa Aesthetic Center, namely:

1) in an increasingly competitive business environment the company needs to apply a Balanced Scorecard in strategic planning and measurement of the company's performance in order to realize the vision and mission of the company by conducting a careful planning,

2) in the preparation of the company's strategic plan to make it more detailed and more fit to the size that has been achieved and in order to bring about improvement in the years to come.

\section{References}

[1] Nugroho, R. L., Pangeran, P. (2021). Improving the performance of the balanced scorecard through implementing iso 31000 risk assessment at shofa pharmacy. EUREKA: Social and Humanities, 1, 23-36. doi: http://doi.org/10.21303/2504-5571.2021.001635

[2] Sinulingga, N. A. (2014). Pengaruh Pendidikan Dan Latihan Tenaga Kerja Terhadap Peningkatan Produktivitas Kerja Pegawai PT. Shamrock Corpora. J. Mantik Penus, 15 (1), 1-7.

[3] Widhiyaningrat, W. A. (2015). Pengukuran Kinerja Organisasi Nirlaba dari Perspektif Balanced Scorecard pada Rumah Sakit Umum Haji Surabaya. Jurnal Ilmu dan Riset Akuntansi, 4 (5), 1-20.

[4] Soedjono, S. (2005). Pengaruh budaya organisasi Terhadap kinerja organisasi dan kepuasan kerja karyawan pada terminal penumpang umum di surabaya. Jurnal Manajemen dan Kewirausahaan, 7 (1), 22-47.

[5] Yuwono, S., Sukarno, E., Ichsan, M. (2007). Petunjuk Praktis Penyusunan Balanced Scorecard: Menuju Organisasi yang Berfokus pada Strategi. Jakarta: Gramedia Pustaka Utama.

[6] Hanafy, M. S. (2014). Konsep belajar dan pembelajaran. Lentera Pendidikan : Jurnal Ilmu Tarbiyah Dan Keguruan, 17 (1), 66-79. doi: http://doi.org/10.24252/lp.2014v17n1a5

[7] Kaplan, D. P., Norton, R. S. (1996). Using the Balanced Scorecard as a Strategic Management System. Boston: Harvard Business Review.

[8] Creswell, J. W. (2014). Qualitative inquiry \& research design: choosing among five approaches. Thousand Oaks: Sage. 
[9] Phytanza, D. T. P., Burhaein, E. (2020). The Effects of Tenure, Teacher Certification, and Work Motivation on Special Needs Teacher Performance. Universal Journal of Educational Research, 8 (9), 4348-4356. doi: http://doi.org/10.13189/ ujer.2020.080962

[10] Burhaein, E., Tarigan, B., Phytanza, D. T. P. (2020). The experiences and understandings of the K-13 curriculum implementation of Indonesian teachers of Adapted Physical Education (APE). International Sports Studies, 42 (3), 29-42. doi: http:// doi.org/10.30819/iss.42-e.04

[11] Miles, M. B., Huberman, A. M., Saldana, J. (2014). Qualitative data analysis: A methods sourcebook. Thousand Oaks: Sage.

[12] Hameed, S., Amjad, A. (2009). Impact of office design on employees productivity: a case study of banking organizations of Abbottabad, Pakistan. J. Public Aff. Adm. Manag., (3 (1)), 1-13.

[13] A. Widyastuti, I., Indriana, T., Umar, I., Bawono, A. (2018). Analisis Kinerja Perusahaan Dengan Metode Balanced Scorecard (Studi Kasus PT XYZ Bergerak Di Bidang Telekomunikasi). Jurnal Administrasi Dan Kesekretarisan, 2 (2), $124-137$.

[14] Kaplan, D. P., Norton, R. S. (2000). Balanced Scorecard: Menerapakan Strategi Menjadi Aksi. Jakarta: Erlangga.

[15] Gaspersz, V. (2011). Sistem Manajemen Kinerja Terintegrasi Balanced Scorecard dengan Malcolm Baldrige dan Lean Six Sigma Supply Chain Management. Bogor: Vinchristo Publication, 470.

[16] Fitriyani, D. (2014). Balanced Scorecard: alternatif Pengukuran Kinerja Sektor Publik. Jurnal Cakrawala Akuntansi, 6 (1), $16-31$.

[17] Fatimah M. H., Kurdi, S., Thamrin, F. N. (2016). Strategi Peningkatan Kinerja dengan Metode Balanced Scorecard di Rumah Sakit Umum Daerah Kabupaten Ogan Ilir. Jurnal Kedokteran dan Kesehatan, 3 (1), 351-359.

[18] Tahaka, Y. K. (2013). Penerapan Balance Scorecard sebagai Alat UkurKinerja pada PT. BANK Sulut. Jurnal EMBA, 1 (4), $402-413$.

Received date 25.06.2021

Accepted date 23.07.2021

Published date 30.07.2021
(C) The Author(s) 2021

This is an open access article under the Creative Commons CC BY license

How to cite. Ruli, C., Kristanto, H. (2021). Implementation of balance scorecard and key performance indicator on customer service employee productivity. EUREKA: Social and Humanities, 4, 26-32. doi: http://doi.org/10.21303/2504-5571.2021.001988 